\title{
Handling Children Dental Caries through Parents Awareness on Community Service
}

\author{
Diyah Fatmasari, Irma HY Siregar, Lanny Sunarjo \\ \{fatmasaridiyah@gmail.com\} \\ Poltekkes Kemenkes Semarang, Indonesia
}

\begin{abstract}
Elementary school children have been categorized as high risk caries group. Maintaining dental health of elementary school need parents' role on making dental care decisions. Srondol Kulon Elementary School and Meteseh Elementary School are 2 elementary schools assisted by Poltekkes Kemenkes Semarang. Two schools located at urban and rural area therefore they have different characteristics of parents. Community service was carried out in 2 elementary schools with the aim to find differences of parental involvement in the promotion, prevention and treatment of children's dental health. Screening was done in class III, then their parents with children who have caries were counseled and educated about dental health. The parents were also given information about children's dental health plan treatment. Informed consent was given to parents in children who would be curated (fillings and extractions). Parent participation in Srondol Elementary School was higher than Meteseh. There was a change in the composition of caries prevalence, increasing in the number of filling permanent and milk teeth (f and F) and extracted (e). Parents' awareness of the importance of treating caries in children as early as possible is higher in Srondol Kulon Elementary School compared to SD Meteseh. Besides, the level of education and parents' socio-economic influenced parents' attitudes in giving decisions of dental treatments.
\end{abstract}

Keywords: Community service, parental involvement, prevalence of caries.

\section{Introduction}

National research[1][2] of Health 2013 has found that the dental caries prevalence among children in Indonesia has increased 13,7\%. DMF-T index among 12 years old children has increased from 0.91 to 1.4 . It means that there are 140 decays among 100 children nowadays[3]. This condition happened[4-6] due to the lackless participation of parents and their children in maintaining their teeth[7-10].Besides, the high consumption of sweet and sticky snacks in school could be the trigger of dental caries [8]. Due to this condition, the community service program could be the other solution to reduce the dental caries among school children. Community service program is one of the university program to interfere the risk community in handling their problems. Through this program, this risk community was given promotive, preventive and simple curative treatments freely (without any charge of payment). This program was designed to solve the community health problems in order to develop national wellbeing [3]. The target of this program was 110 students of two elementary school students (Srondol Kulon and Meteseh Elementary School Semarang) and their parents. Indicators success of the community service activities are:

a. Changing student behavior about brushing teeth 
b. Filling the Permanent teeth's caries among grade III elementary school students

c. Extracting the Milk teeth with physiological persistence and resorption

d. The involvement of parents by signing an informed consent that shows parents attention to their child's dental care

Purpose of the program was to compare parent's awareness of their children dental health related to promotive, preventive and curative program and to change the composition of caries prevalence from decay to filling and extraction of milk teeth

\section{Methodology}

Community Service Program is a yearly program and as a part of lecture obligation to community. Handling dental caries of children is very crucial to decrease prevalence caries at Indonesia. Community service involved three programs : Promotive, Preventive and Simple Curative. The promotive activities were given to the parents and students. The preventive and simple curative treatments were given to the students only. All these activities were implemented in school. Simple clincic equipments were brought into class which was designed as "clinic". The target of this program was 110 students of two elementary school students (Srondol Kulon and Meteseh Elementary School Semarang) and their parents. The activities were :

\section{a. Promotive activities}

Students' parents were taught about maintaining children's dental health. They were informed about the growth of teeth process, dealing with mixed dentition period, handling mixed dentition problems and the right way on brushing the teeth. The postition and condition of teeth in mixed dentition period could be a trigger of having a decay. Parents should know how to monitor their children in maintaing their teeth during this periode. Their concern was so important that could prevent dental caries in this period[2]. Students were also taught about the importance of caring their teeth and the right way on brushing their teeth.

\section{b. Preventive activities}

Students brushed their teeth together in the right way under guidance of dental nurse's students. After brushing their teeth, they were examined for screening their dental problems. The indexes used to measure caries experience are DMF-T (Decay Missing Filling Teeth) for permanent teeth and def-t (decay extraction filling teeth) for milk teeth [4].

\section{c. Simple curative treatments}

The treatments given were simple filling with GIC (Glass Ionomer Cement), milk teeth extractions and refferal treatments by dentists and dental nurses. The priorities of treatments were filling the email and dentin decay and extracting the milk teeth. Not all decay teeth could be filled out due to its severity[1] so some of them were refereed for the next treatment in Puskesmas (Government Community Health Centre). Some untreated carious teeth - even they could give problems in eating and sleeping, malnutrition and alterations in growth and 
development - could not be extracted due to the period time of permanent growth which replaced them[9]. Parents whose children had simple curative treatments had to fill informed consent which indicate their awareness of children dental health. The sequence of this community service activities was:

a. Screening for all third grade students of Srondol Kulon Elementary School (urban area) and Meteseh Elementary School (rural area)

b. Reporting students' data which required dental care to the Principal

c. Inviting all parents and students to be given education about dental health

d. Parents signed an informed consent indicating they expressed no objection on their children's dental treatments

e. Children were given demonstrations on how to brush their teeth and did the right procedure of brushing their teeth on mass tooth-brushing activities

f. Simple curative actions were taken: extraction of milk teeth, filling the caries of milk teeth and permanent teeth and scaling

g. Making reports to the school

\section{Results and Discussion}

The change of prevalence caries were reported on the table below:

Table 1. Student's Teeth Condition Before and After Community Service Treatments

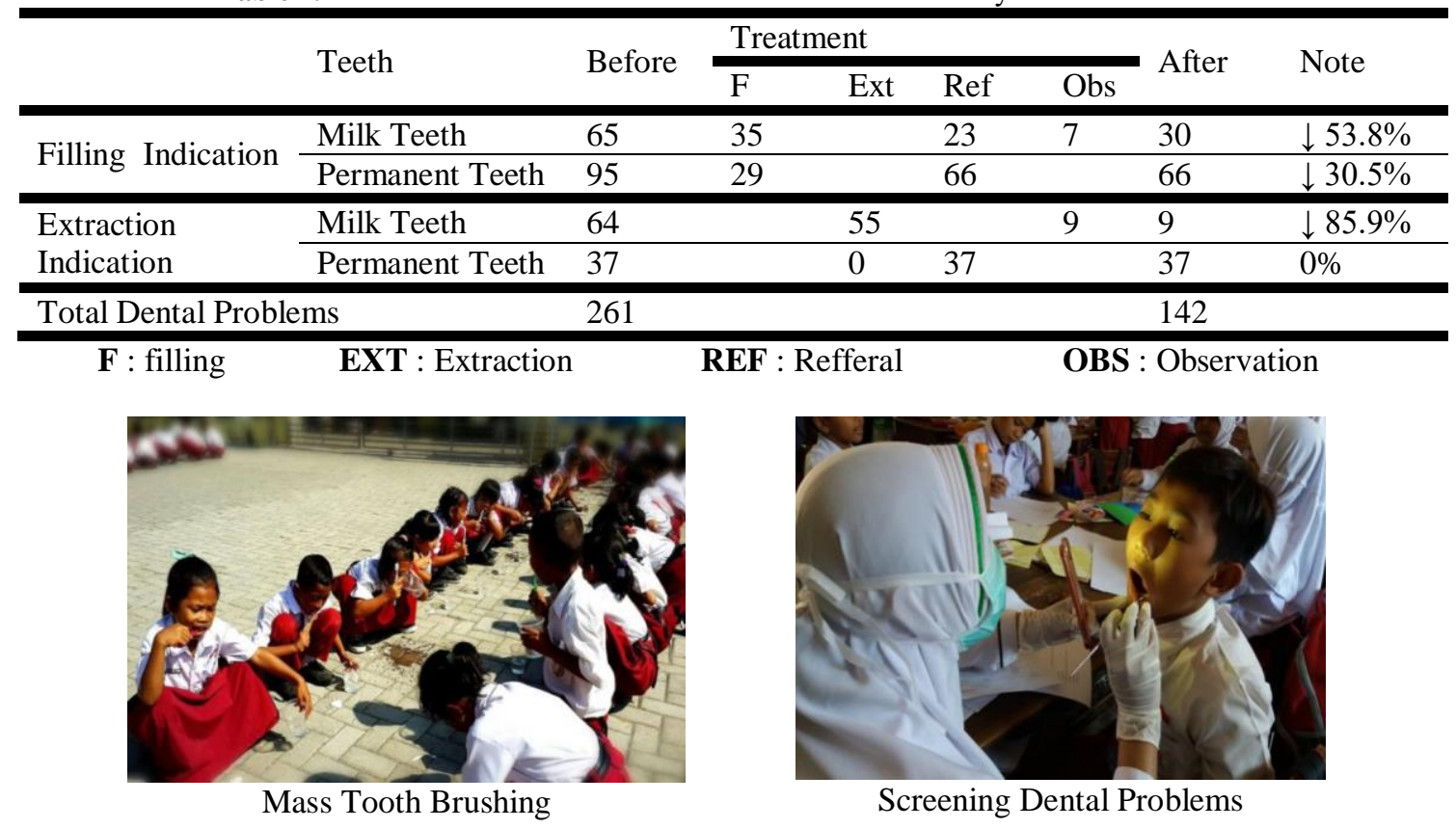






Parents' Promotive

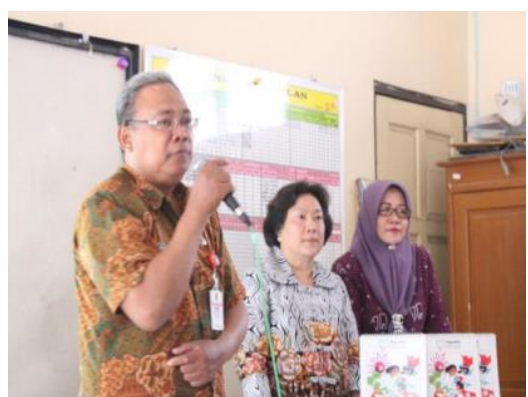

School Headmaster's Support

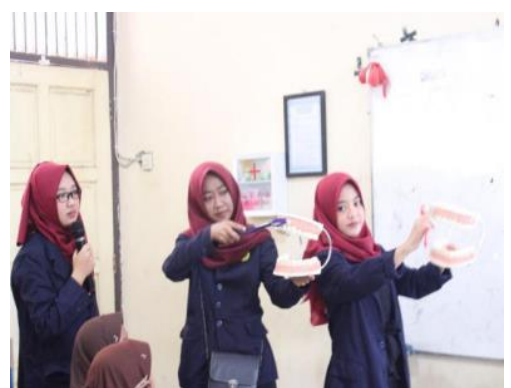

Tooth-Brushing Demonstration

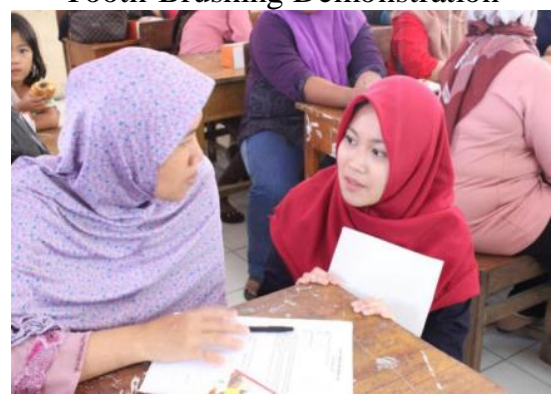

Pare Informed Consent (Parents Signatures)

These three activities of community service could decrease the filling and extraction indications on milk teeth $(53.8 \%$ and $85.9 \%)$ and the decays on permanent teeth around $30.5 \%$. Not all the problems could be done completely in this study. There were 119 dental problems handled completely from 261 found dental problems. In other word, solved dental problems were around $45.59 \%$. The untreatment teeth or unsolved dental problems were reffered to Puskesmas.If this community service was implemented every year, the dental caries prevalence among childred would decrease optimally.

Parent's awareness of the two elementary school was quite different. Parents from Elementary School Srondol Kulon which located at urban area were more aware of their children's dental health. Only 5 of 60 parents who disagree ( $92 \%$ agree) on having curative treatments for their children while from 50 parents from Elementary School Meteseh 30 parents gave agreement (60\% agreed) by signing informed consent. Parents from Elementary of School Srondol Kulon which located at urban area has higher level of education compared to parents from Elementary School Meteseh which located at rural area. Socio Economic status (SES) of parents at urban area were relative higher than parents from rural area. According to Wen and Kaneda (2010), China has different level of SES and urban community has more access to health services. Most parents from urban school worked as government employee, doctor and entrepreneur while parents at rural area worked as market seller or opened shop at home. Education level and socioeconomic status influence parental knowledge and thus related with their attitude on dental health.

These three activities of community service could decrease the filling and extraction indications on milk teeth $(53.8 \%$ and $85.9 \%)$ and the decays on permanent teeth around $30.5 \%$. Not all the problems could be done completely in this study. There were 119 dental problems handled completely from 261 found dental problems. In other word, solved dental problems were around $45.59 \%$. The untreatment teeth or unsolved dental problems were refereed to 
Puskesmas.If this community service was implemented every year, the dental caries prevalence among children would decrease optimally.

Parent's awareness of the two elementary school was quite different. Parents from Elementary School Srondol Kulon which located at urban area were more aware of their children's dental health. Only 5 of 60 parents who disagree ( $92 \%$ agree) on having curative treatments for their children while from 50 parents from Elementary School Meteseh 30 parents gave agreement (60\% agreed) by signing informed consent. Parents from Elementary of School Srondol Kulon which located at urban area has higher level of education compared to parents from Elementary School Meteseh which located at rural area. Socio Economic status (SES) of parents at urban area were relative higher than parents from rural area. According to Wen and Kaneda (2010), China has different level of SES and urban community has more access to health services. Most parents from urban school worked as government employee, doctor and entrepreneur while parents at rural area worked as market seller or openedd shop at home. Education level and socio economic status influence parental knowledge and thus related with their attitude on dental health

\section{Conclussion}

Based on community service which implemented at two school at Semarang we could conclude:

a. Parent's involvement at children dental health are important to handling dental caries.

b. Parents awareness are higher at urban area than rural area

c. Around $45.59 \%$ of dental problems are solved, which indicated by increase of permanent teeth filling and extraction of deciduous teeth (resorption physiologist and persistency)

\section{Acknowledgements}

We would like to thank the Poltekkes Kemenkes Kesehatan for providing financial support for the study, and thanks to the participants for taking part in this study. The authors declare that there is no conflict interests.

\section{References}

[1] Harrison L. , (2017), Don't't touch that carious dentin, available at http://www.drbicuspid.com/index.aspx? sec $=$ ser $\& s u b=d e f \& p a g=d i s \& I t e m I D=304036$

[2] Ircham, (2005) MenjagaKesehatan Gigi danMulutAnak-AnakdanIbuHamil, cetakan ke-1: Fitramaya: Yogyakarta.http://perpustakaan-wiryawanfamily.blogspot.co.id/2012/11/menjagakesehatan-gigi-dan-mulut-anak.html

[3] Infodatin Kementerian Kesehatan R www.depkes.go.id/download.php?file=download/pusdatin/infodatin/infodatin-gilut

[4] Lamas M. (2010), Has dental caries prevalence some connection with caries index values in adults?,Caries Research, 44 (1). https://www.ncbi.nlm.nih.gov/pubmed/20130404

[5] Menristekdikti, (2016), PanduanPelaksanaan Penelitian dan Pengabdian Masyarakat di Perguruan $\begin{array}{llll}\text { Tinggi } & \text { Edisi } & X & \text { Tahun }\end{array}$ http://simlitabmas.dikti.go.id/fileUpload/pengumuman/Panduan_Pelaksanaan_Penelitian_dan_PP M_Edisi_\%20EDISI_X_2016.pdf 
[6] Ming Wen, Toshiko Kaneda, 2010, A multi-level analysis of urban/rural and socioeconomic differences in functional health status transition among older Chinese, SocSci Med , 7 (13): 559567, available at https://www.ncbi.nlm.nih.gov/pmc/articles/PMC2904335/

[7] NagaveniNB, Radhika NB, Umashankar KV, (2011), Knowledge, attitude and practices of parents regarding primary teeth care of their children in Davangere city, India. Pesq Bras OdontopedClinIntegr, Joao Pessoa, $11(1): 129$ 132.http://revista.uepb.edu.br/index.php/pboci/article/viewFile/1268/626

[8] Nunn ME, Braunstein NS, Krall Kaye EA, Dietrich T, Garcia RI, Henshaw MM. (2009) Healthy eating index is a predictor of early childhood caries. $J$ Dent Res.88(4):3616.10.1177/0022034509334043, https://www.ncbi.nlm.nih.gov/pubmed/19407158

[9] Schroth RJ, Harrison RL, Moffatt ME. (2009) Oral health of indigenous children and the influence of early childhood caries: on childhood health and wellbeing. PediatrClin North Am. ;56(6):14811499. https://www.ncbi.nlm.nih.gov/pubmed/19962032

[10] Setty JV, Srinivasan I (2016), Knowledge and Awareness of Primary Teeth and Their Importance among Parents in Bengaluru City, India, International Journal of Clinical Pediatric Dentistry, 9 (1): 56-61, https://www.ncbi.nlm.nih.gov/pmc/articles/PMC4890064/ 